\title{
EFFECT OF LOCAL TREE SEEDS IN THE CONTROL OF ROOT KNOT NEMATODE Meloidogyne javanica (TREUB) CHITWOOD AND GROWTH PROMOTION OF CHICKPEA (Cicer arietinum L.) AND MUNG BEAN (Vigna radiata $\mathbf{L}$.)
}

\author{
Zainab Mushtaq Ahmed, Shahnaz Dawar, Marium Tariq, Muhammad Javed Zaki
}

\author{
Department of Botany, University of Karachi, Karachi-75270, Pakistan \\ email: shahnaz_dawar@yahoo.com
}

Received: 3.08 .2009

\begin{abstract}
Seeds of local trees, such Azadirachta indica A. Juss, Adenanthera pavonina L., Leucaena leucocephala (Lam.) de Wit and Eucalyptus spp., were used as aqueous extract at 25, 50 and $100 \%$ concentration to control the activity of Meloidogyne javanica (Treub) Citwood. All seed extracts showed lethal effect on $M$. javanica eggs, and a gradual decrease in egg hatching and an increase in mortality of second-stage juveniles were observed with the increase in extract concentration. L. leucocephala was found to be most effective in reducing egg hatching, whereas $100 \%$ mortality of juveniles was observed in the case of $A$. indica seed extract. Number of knots was significantly reduced at $100 \%$ concentration when seeds of chick pea and mung bean were treated and soil was drenched with $A$. pavonina and Eucalyptus spp. seed extract.
\end{abstract}

Key words: Local tree seeds, nematicidal properties, plant extract, Meloidogyne javanica, mung bean and chick pea, growth promotion.

\section{INTRODUCTION}

The allelochemicals released from various plant parts eventually penetrate the soil and not only hinder the normal growth of the neighbouring plants but may also affect development and reproduction of many plant parasitic nematodes (D' Addabbo, 1995). Root-knot nematodes (RKN) are one of the most important nematode pests of crop plants and have a diverse host range. RKN (Meloidogyne spp.) are sedentary root endoparasites and are involved in the development of specialized feeding structures known as giant cells. Root knot nematodes (Meloidogyne spp.) are capable of reproducing on over 2,000 species of plants (S a s ser and Freckman, 1987) and are responsible for approximately $50 \%$ of overall nematode damage. The various species of Meloidogyne induce major morphological and physiological changes within roots, attack nearly every crop sown, where not only yields are greatly affected but quality is also reduced (S a s s e r, 1980). Various plants extracts like Eucalyptus sp., (D a w a r et al. 2007) Avicennia marina, Rhizophora mucronata, Ceriops tagal and Aegiceras corniculatum were reported against root knot nematode (Mehdi and Dawar, 2008). Goswami and Vija y lak sh mi (1986) reported that the number of galls per $\mathrm{g}$ of root was reduced by 9 different plant extracts especially with Euclipta alba, Shorea rubuta and Datura metal. Leaf extracts of Ricinus communis were found the most toxic to $M$. incognita. It is quite obvious that mature seeds of neem synthesize more metabolic substances like azadirachtin and other closely related metabolites - vepaol, isovepaol and nimibidin - which have been stated to be antifeedant and growth inhibitor of insects by $\mathrm{S}$ a $\mathrm{n} \mathrm{k} \mathrm{a} \mathrm{r} \mathrm{a} \mathrm{m} \mathrm{et} \mathrm{al.}$ (1986). Such synthesized metabolites in mature seeds of neem accumulate in more concentrated form and are likely to be more lethal to the plant pathogen, including nematodes, allowing better plant growth. Leucaena leucocephala (Lam.) de Wit, commonly known as tangan-tangan or Leucaena, is a leguminous shrub or tree grown in tropical and subtropical regions. Neem, Azadirachta indica A Juss (Meliaceae), is an evergreen, multipurpose tropical tree. Adenanthera pavoni$n a$ (L.) (family Leguminosae,) has long been an important tree in Southeast Asia and the Pacific Islands (B u rki11, 1966). The genus Eucalyptus (Myrtaceae) forms an integral part of the Australian flora, including $>800$ species that dominate most forest types, from coastal to subalpine habitats (Willi a m s and B r o o ker, 1997). The aim of the present study was 
to determine the effect of aqueous extract of local tree seeds infecting mung bean (Vigna radiata L.) and chick pea (Cicer arietinum L.).

\section{MATERIALS AND METHODS}

Collection of material: Seeds of A. indica, A. pavonina, L. leucocephala and Eucalyptus spp., were collected from the Karachi University campus, washed under running tap water, air dried and then homogenized to fine powder and stored in air tight bottles for further studies.

Extract preparation: Aqueous extract (10\% concentration) was prepared by soaking the powder for 48 hours in sterilized distilled water. After staining through muslin cloth, it was filtered through Whatman No.1 filter paper. Half quantity of $100 \%$ extract was diluted in sterilized distilled water, which gave $50 \%$ extract and $25 \%$ extract.

Culture preparation of root knot nematodes: Roots of plants infested with root-knot nematodes were collected from the Karachi University garden. The root knot nematodes were identified with the help of perennial pattern as described by $\mathrm{T}$ a y $\mathrm{l}$ or and $\mathrm{N}$ e $\mathrm{t} \mathrm{c} \mathrm{ch}$ e $\mathrm{r}$ (1974). The root-knot nematode M. javanica (Treub) Chitwood was cultured on brinjal Solanum melongena L.) seedlings in a greenhouse from a single egg mass. Nematode eggs were extracted from infected roots using a $2 \% \mathrm{NaOCl}$ solution and the eggs released from the roots were collected using the modified technique described by M c Clure et al. (1973). The egg suspension was poured on a cotton-wool filter paper and incubated at $28 \pm 2^{\circ} \mathrm{C}$ to obtain freshly hatched juveniles $\left(\mathrm{J}_{2}\right)$. Juveniles were collected within $48 \mathrm{~h}$ and used.

Egg hatching test: To determine the effect of aqueous extract of seed powder from local tree seeds on egg hatching activity of $M$. javanica, two $\mathrm{ml}$ of the seed extract $(25,50$ and $100 \%$ concentration) of local trees was transferred onto watch glasses (diameter 2.5 $\mathrm{cm}$ ) into which two medium size egg masses, handpicked from the knots of egg plant, were placed. Egg masses kept in distilled water served as control. Each treatment was replicated thrice. After $72 \mathrm{~h}$ exposure, the number of juveniles hatched was counted with the aid of a stereomicroscope (X 6). Treatments were triplicate and watch glasses were randomized at room temperature $\left(28 \pm 2^{\circ} \mathrm{C}\right)$. The toxicity of local tree seed extract was assessed as the mean percentage of the hatched eggs.

Mortality test: Eggs/egg masses of M. javanica were placed in distilled water and incubated at $28 \pm 2^{\circ} \mathrm{C}$. After hatching, the juveniles were collected and a suspension of juveniles in distilled water was prepared. Two $\mathrm{ml}$ of suspension of freshly hatched juveniles (40-50 juveniles/ml) and two $\mathrm{ml}$ of extra- ct $(25,50$ and $100 \%$ concentration) were added to each glass slide to assess juvenile mortality and it was kept at room temperature $\left(28 \pm 2^{\circ} \mathrm{C}\right)$. Each treatment was replicated thrice. The glass cavity block without aqueous extract served as control. After $72 \mathrm{~h}$ exposure, the number of killed juveniles was counted under a low power stereomicroscope. The toxicity of spices was assessed as the mean percentage of dead nematodes. Nematodes were considered dead if they did not move when probed with a fine needle ( $\mathrm{C}$ ay rol et al. 1989).

Soil used for green house experiment Pots (300 gm) were filled with soil obtained from experimental plots of the Botany Department, University of Karachi. Before filling the pots, soil was analysed for $\mathrm{pH}$ (7-7.6), moisture holding capacity (MWHC) of 40\% (Ke e n and R a ckowski, 1922), total nitrogen $0.077-0.099 \%$ (Mackenzie and Wallace, 1954).

Application as seed coating and soil drenching Seeds of mung bean and chick pea were surface sterilized with $1 \% \mathrm{Ca}\left(\mathrm{OCl}_{2}\right)$ for 3 minutes, rinsed thoroughly in running tap water and dried aseptically. Surface disinfested seeds were treated with 25 , 50 and $100 \%$ seed extract of A. indica, A. pavonina, L. leucocephala and Eucalyptus spp. 5 seeds were sown in $8 \mathrm{~cm}$ diam. plastic pots. For soil drenching, $25 \mathrm{ml}$ aqueous extracts of local tree seeds at $25 \%$, $50 \%$ and $100 \%$ concentration each were drenched in the pots. Seeds and soil treated with sterilized distilled water served as control. The pots were placed in a greenhouse of the Department of Botany, University of Karachi, with natural sunlight, in a randomized design and there were three replicates per treatment. Fifteen days after mung bean and chick pea seedling emergence, the soil in each pot was inoculated with 2000 juveniles of $M$. javanica by pouring the nematode suspension into holes made around the roots of each plant. The juveniles were less than one week old and were obtained from infected brinjal (Solanum melongena L.). Observations were recorded after 8 weeks of nematode inoculation by determining the number of galls per root system and recording the growth indices of mung bean (Vigna radiata L.) and chick pea (Cicer arietinum $L$.) plants.

Statistical analysis The obtained data were analyzed and subjected to analysis of variance (ANOVA) and means were compared for significance by the Least Significance Difference (LSD) method at the probability of 0.05 (S o kal and R o h lf, 1995).

\section{RESULTS}

Effect on hatching and mortality of $M$. javanica Aqueous extracts of powdered seeds of $A$. indica, 
A. pavonina, L. leucocephala and Eucalyptus spp., inhibited M. javanica eggs hatching with the increase in exposure time. Complete reduction of eggs of $M$. javanica was observed when $L$. leucocephala was used at $100 \%$ concentration $(100 \%)$, followed by $50(96.29 \%)$ and $25 \%$ concentration $(92.59 \%)$ where 1 and $2 \%$ eggs were hatched after $72 \mathrm{hrs}$ (Table 1). Appreciable mortality of juveniles was observed when $100 \%$ concentration extract of $A$. indica was used, followed by $100 \%$ concentration of $A$. pavonina $(154.28 \%)$, L. leucocephala $(413.89 \%)$ and Eucalyptus spp., $(80.64 \%)$ after $72 \mathrm{hrs}$ of exposure to room temperature. As compared to different concentrations of the extract used, $100 \%$ concentration was found to cause more mortality and less egg to be hatched (Table 1).

Table 1

Effect of local tree seed powder on egg hatching and mortality of Meloidogyne javanica

\begin{tabular}{|c|c|c|c|c|c|c|c|}
\hline \multirow[b]{2}{*}{ Treatment } & \multicolumn{3}{|c|}{ HATCHING \% } & \multicolumn{4}{|c|}{ MORTALITY \% } \\
\hline & 24 Hours & 48 Hours & 72 Hours & $\begin{array}{l}\text { Population } \\
\text { at } 0 \text { day }\end{array}$ & 24 Hours & 48 Hours & 72 Hours \\
\hline Control & 12 & 22 & 27 & 30 & 0 & 0 & 0 \\
\hline Azadirachta indica $(25 \%)$ & $9(25)$ & $11(50)$ & $18(33.34)$ & 25 & $12(52)$ & $12(52)$ & $20(20)$ \\
\hline Azadirachta indica (50\%) & $5(58.34)$ & $5(77.28)$ & $12(55.56)$ & 22 & $14(36.37)$ & $44(100)$ & $50(127.27)$ \\
\hline Azadirachta indica $(100 \%)$ & $4(66.67)$ & $6(72.73)$ & $7(74.08)$ & 30 & $33(43.4)$ & $87(278.26)$ & $100(334.78)$ \\
\hline Adenanthera pavonina (25\%) & $2(83.34)$ & $6(72.73)$ & $7(74.08)$ & 32 & $0(100)$ & $44(37.5)$ & $44(37.5)$ \\
\hline Adenanthera pavonina (50\%) & $8(33.34)$ & $8(63.64)$ & $9(66.67)$ & 28 & $44(57.14)$ & $56(100)$ & $67(139.28)$ \\
\hline Adenanthera pavonina (100\%) & $5(58.34)$ & $7(68.19)$ & $8(70.38)$ & 35 & $78(122.85)$ & $78(122.85)$ & $89(154.28)$ \\
\hline Leucaena leucocephala (25\%) & $1(91.66)$ & $2(90.91)$ & $2(92.59)$ & 39 & $23(41.03)$ & $23(41.03)$ & $23(41.03)$ \\
\hline Leucaena leucocephala (50\%) & $1(91.66)$ & $1(95.45)$ & $1(96.29)$ & 42 & $17(59.53)$ & $17(59.53)$ & $17(59.53)$ \\
\hline Leucaena leucocephala (100\%) & $0(100)$ & $0(100)$ & $0(100)$ & 36 & $72(100)$ & $85(413.88)$ & $85(413.88)$ \\
\hline Eucalyptus spp., (25\%) & $5(58.34)$ & $9(59.1)$ & $11(59.26)$ & 28 & $0(100)$ & $0(100)$ & $6(78.57)$ \\
\hline Eucalyptus spp., (50\%) & $11(8.34)$ & $14(36.37)$ & $17(37.04)$ & 29 & $0(100)$ & $6(79.32)$ & $6(79.32)$ \\
\hline Eucalyptus spp., (100\%) & $3(75)$ & $3(86.37)$ & $8(70.38)$ & 31 & $6(80.64)$ & $6(80.64)$ & $6(80.64)$ \\
\hline $\begin{array}{l}\mathrm{LSD}_{0.05} \\
\text { Treatment } \\
\text { Time }\end{array}$ & & $\begin{array}{c}3.9 \\
1.88\end{array}$ & & & & $\begin{array}{l}1.3 \\
0.2\end{array}$ & \\
\hline
\end{tabular}

Parenthesis shows reduction $\%$ or increase $\%$ as compared to control

Effect of seed treatment on growth indices and number of galls The seeds of chickpea and mung bean were treated with 25,50 and $100 \%$ concentration of extract of A. indica, A. pavonina, L. leucocephala and Eucalyptus spp. There was a decrease in severity of root galling observed when chickpea seeds were treated with $100 \%(87.18 \%)$ concentration of A. pavonina as compared to mung bean (80.69\%) (Table 2). The germination was highest when mung bean seeds were treated with $100 \%$ concentration of A. pavonina
(28.58\%) and Eucalyptus spp., (28.58\%). Seed treatment with $A$. indica at $100 \%$ concentration caused an increase in the length of shoot (25.83\%) and root (98.51\%) of chickpea, whereas root weight $(54.16 \%)$ (60.41\%) showed significant increase when Eucalyptus spp., seed powder extract was used at 50 and $100 \%$ concentration. A significant increase in shoot length $(7.48 \%)$ of mung bean plants was observed when seeds were treated with $100 \%$ concentration of $A$. pavonina (Table 2 ). 
党

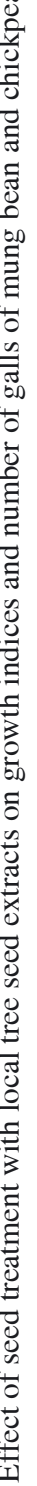

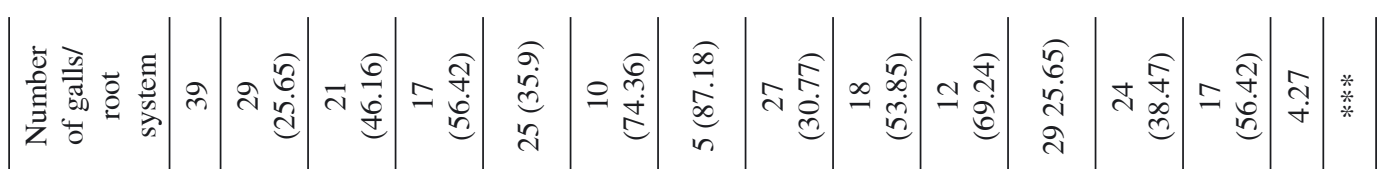

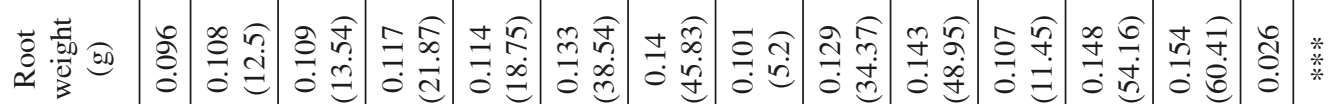

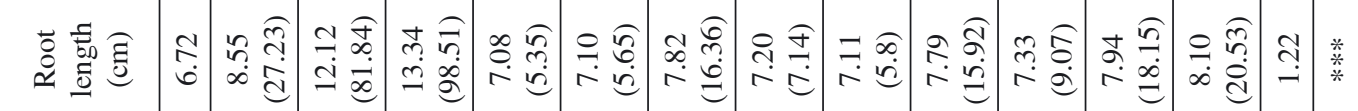

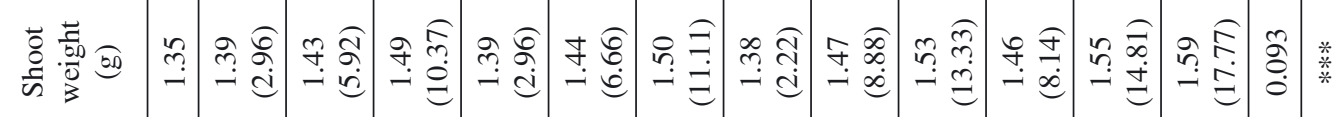

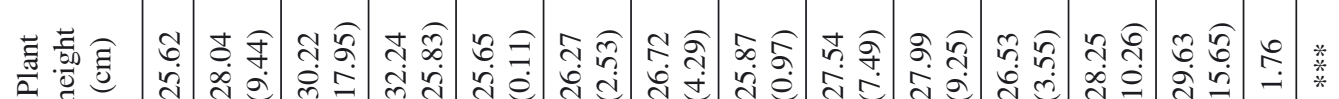

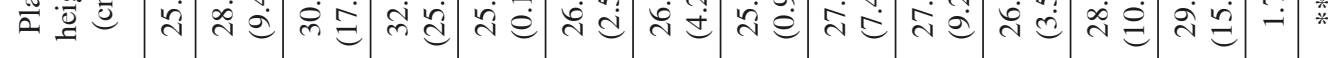

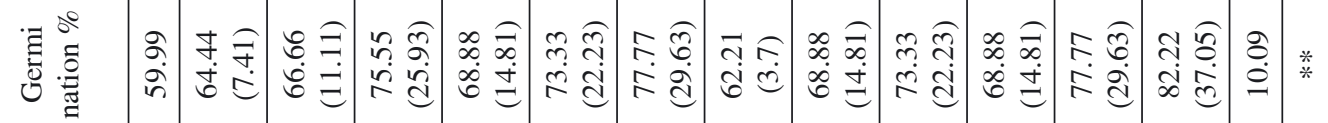

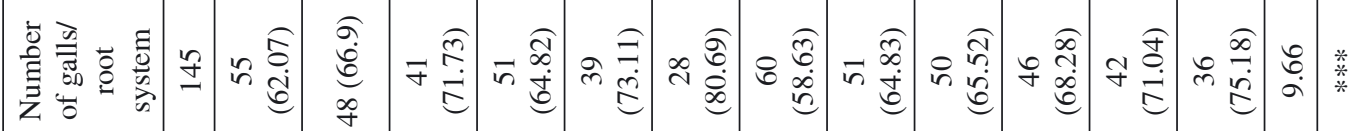

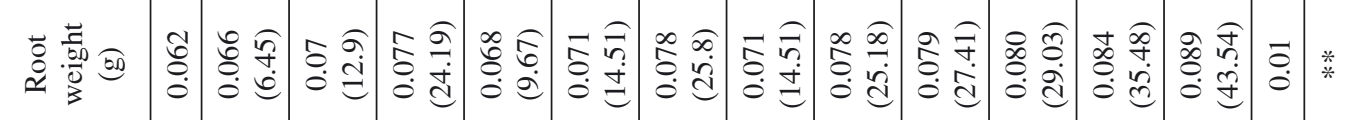

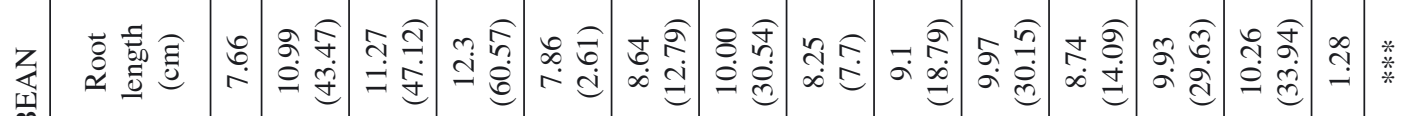

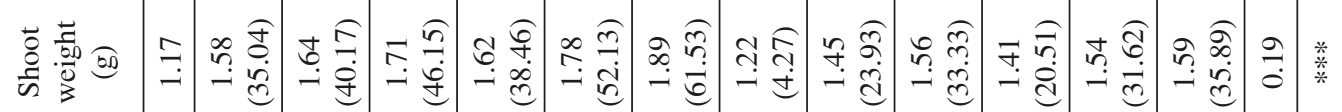

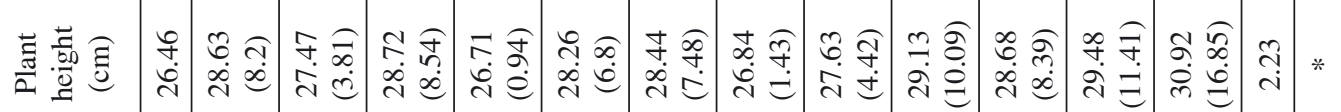

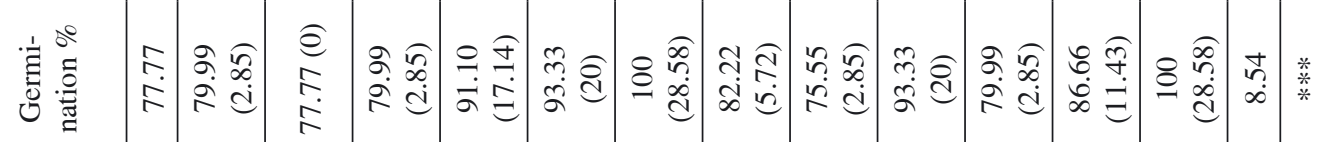
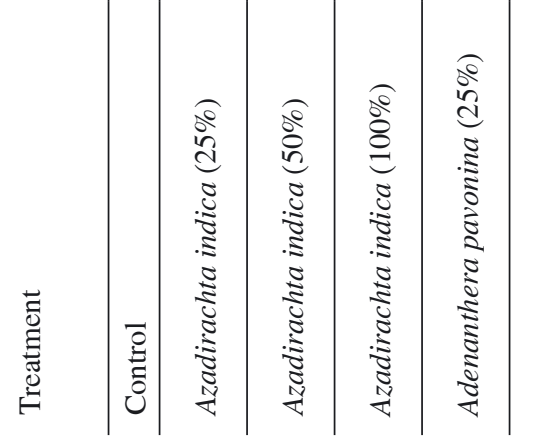

\begin{tabular}{|c|c|c|}
\hline 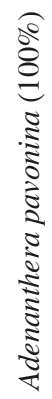 & 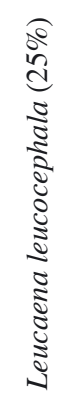 & 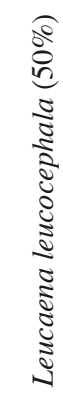 \\
\hline
\end{tabular}

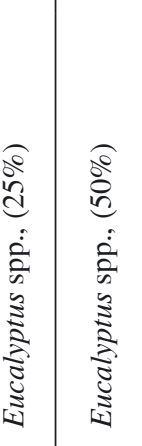




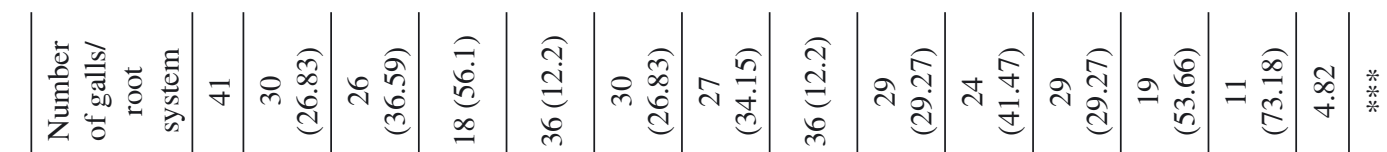

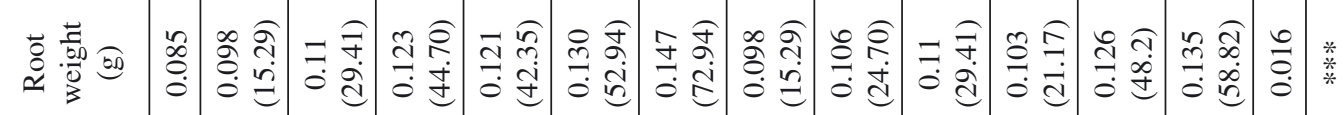

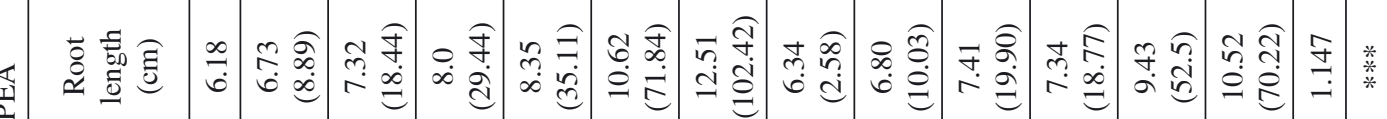

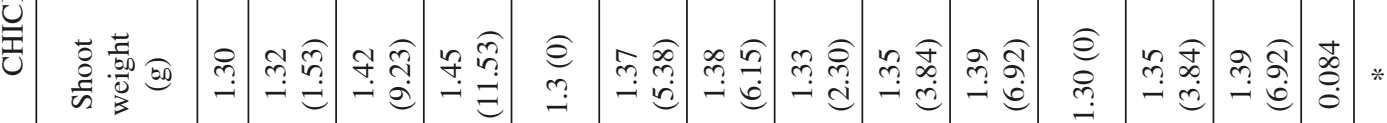

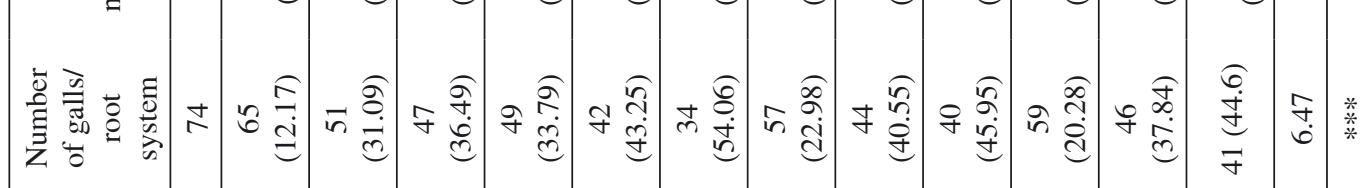

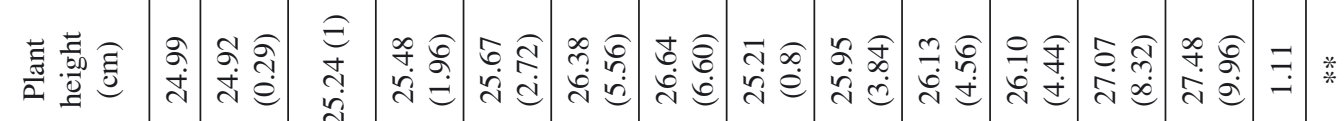

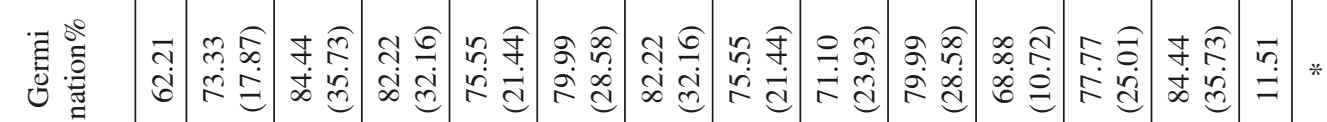

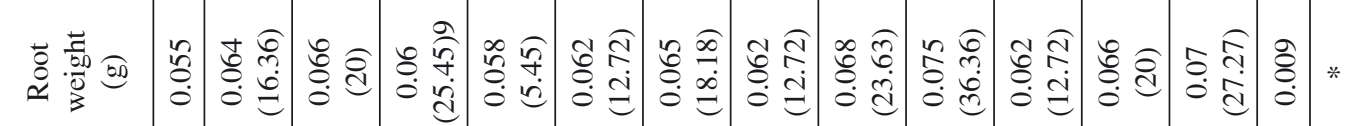

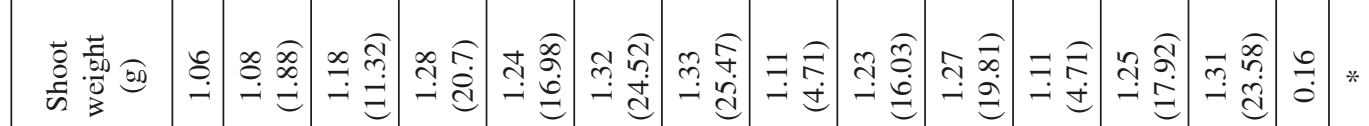

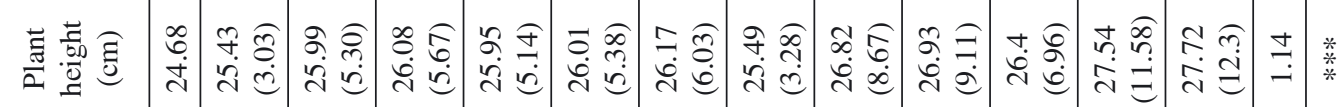

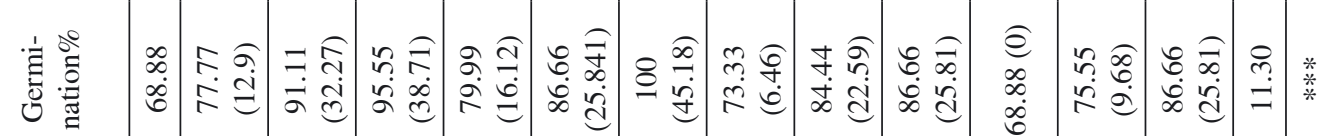

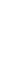


Effect of soil drenching on growth indices and number of galls Soil was drenched with the extract of Eucalyptus spp., at $100 \%$ concentration which reduced the galling rates due to $M$. javanica on cowpea, followed by $A$. indica, L. leucocephala and A. pavonina as compared to control (Table 3). Root length (102.42\%) and root weight $(58.82 \%)$ were increased in chickpea, whereas shoot length $(9.96 \%)(12.3 \%)$ was more or less equally increased in both chickpea and mung bean when $100 \%$ concentration of Eucalyptus spp., extract was used as soil drenching (Table 3). There was an increment in germination of seeds with an increase in concentration of the extract. The degree of inhibition of $M$. javanica infection on roots and the growth indices were equally effective by A. pavonina, A. indica, Eucalyptus spp., followed by $L$. leucocephala extract used as soil drenching (Table 3).

\section{DISCUSSION}

Phytomedicines derived from plants have shown great promise in the treatment of infectious diseases, including viral infections (C o w a n, 1999). The ancient Egyptians were familiar with many medicinal herbs and were aware of their usefulness in treatment of various diseases (A b u - S h a n a b et al. 2004). Several higher plants and their constituents have shown success in plant disease control (A s h r a f u z z a m a and Hossain, 1992; Hos sain and A shrafuz$\mathrm{z}$ a m a n, 1994).

Our results indicate that, with increasing extract concentrations, hatching of eggs was gradually decreased. We suggest that $100 \%$ extract concentration was best for reducing the hatching of eggs, followed by 50 $\%$ concentration. The best nematicidal activity was shown by L. leucocephala which showed $0 \%$ hatching, followed by A. pavonina that showed more promising control of $M$. javanica egg hatching than Eucalyptus spp., and A. indica. Mortality was gradually increased with exposure time. A. indica $100 \%$ concentration extracts showed $100 \%$ mortality, followed by $50 \%$ concentration; then, A. pavonina and L. leucocephala showed 85 and $89 \%$ mortality, respectively, in 100 $\%$ concentration extracts, followed by Eucalyptus spp. Various neem products, including neem cake, its oil and Nimin (containing neem triterpenes) as urea coating agents, and root-dip or seed treatment with neem extracts have been found to be nematicidal against several species of parasitic nematodes (A l a m, 1991), attacking vegetables and legumes ( $\mathrm{H}$ a s e e b et al. 2005).

The present results showed that shoot and root weight were significantly increased when seeds of chickpea were coated with $A$. indica used as $100 \%$ concentration. Neem is widespread in Pakistan and has been found effective in bringing the nematode population below the threshold level ( $\mathrm{J}$ a v e d et al. 2008), which might provide an alternative, sustainable and inexpensive means of managing nematodes. The bioactivity of neem materials against nematodes and insect is attributed to the presence of an array of complex compounds, triterpenes, or more specifically limonoids (A la m, 1993; K r a u s , 1995). However, soil amendment with neem seems to be the most practical method for nematode control (A l a m, 1993).

The seed treatment with A. indica, A. pavonina, L. leucocephala and Eucalyptus spp., showed promising results in controlling the root knot diseases in mung bean and chick pea. This suppression of infection resulted in significant plant growth enhancement. Similar results were shown by Chabra et al. (1988) who noted that leaf extracts of Ricinus communis, Leucaena leucocephala, Populus deltoides, Azadirachta indica, Lantana cámara and Eucalyptus hybrida were highly toxic to $\mathrm{J} 2$ of $M$. incognita. It suggested that neem metabolites were absorbed by the roots to halt the $\mathrm{J} 2$ penetration ( $\mathrm{J}$ a v e d et al. 2007a). The bioactive principles in neem extracts have also been reported to inhibit the penetration of nematodes (Moju m der, 1995).

\section{CONCLUSION}

The use of A. indica, A pavonina, L. leucocephala and Eucalyptus spp., seed extracts as seed treatment and soil drenching has the potential to reduce severity of galls in roots and enhance the plant growth. However, further research including a more quantitative approach is needed to explore the control of damage caused by nematodes.

\section{REFERENCES}

A la m M.M., 1991. Control of plant parasitic nematodes with oilseed cakes on some vegetables in field. Pakistan J. Nematol. 9: 21-30.

Alam M.M., 1993. Bioactivity against phytonematodes. [In]: Neem Research and Development. (Randhawa N.S., Parmar B.S., ed.), Soc. Pesticides Sc., New Delhi, India: 123-143.

A shrafuzzaman H., Hossain I., 1992. Antifungal activity of crude plant extracts against Rhizoctonia solani and Bipolaris sorokiniana. BAU. Res. Progr, 6: 188-192.

B urkill I.H., 1966. A dictionary of the economic products of the Malay Peninsula. Art printing works, Kuala Lumpur. 2 volumes.

Cayrol J.C., Djian C., Pijarowski I., 1989. Studies on the nematicidal properties of the culture filtrate of the nematophagous fungus Paecilomyces lilacinus. Rev. Nematol, 12: 331-336. 
Chabra H.K., Grewal P.S., Singh A., 1988. Efficacy of some plant extracts on root knot nematode (Meloidogyne incognita). J. Tree Sci, 7: 24-25.

Cow an M.M., 1999. Plant products as antimicrobial agents. Clin. Microbiol. Revi, 12: 564-582.

D'Addabbo T., 1995. The nematicidal effect of organic amendments: a review of the literature, 1982-1994. Nematol. Medit, 23: 299-305.

Dawar S., Younus S.M., Tariq M., Zaki M.J., 2007. Use of Eucalyptus sp., in the control of root infecting fungi on mung bean and chick-pea. Pak. J. Bot, 39(3): 975-979.

Goswami B.K., Vijaylakshmi K., 1986. Effect of some indigenous plant materials and oil cake amended soil on the growth of tomato and root-knot nematode population. Ann. Agril. Res, 7: 263-366.

Haseeb A., Anita S., Kumar S.P., 2005. Studies on the management of root-knot nematode, Meloidogyne incognita-wilt fungus, Fusarium oxysporum disease complex of green gram, Vigna radiate cv ML-1108. J. Zhejiang Univ. Sc., 6B: 736-742.

Hossain I., Ashrafuzzaman H., 1994. Control of Rhizoctonia solani and Bipolaris sorokiniana with crude plant extracts. BAU. Res. Progr, 8: 86-92.

Javed N., Gowen S.R., Haq M.I., Anwar S.A., 2007a. Protective and curative effect of neem formulations on the development of root knot nematode, Meloidogyne javanica in roots of tomato plants. Crop protection, 26: 530-534.

Javed N., Gowen S.R., E1-Hassan S.A., Inamul-Haq M., Shahina F., Pembroke B., 2008. Efficacy of neem (Azadirachta indica) formulations on biology of root-knot nematodes (Meloidogyne javanica) on tomato. Crop Protection, 26: 530-534.

Keen B.A., Raczkowski H., 1922. The Kjeldahl determination of nitrogen. A critical study of digestion condition, temperature, catalyst and oxidizing agent. Aust. I. Chem, 7: 55-70.

K rau s W., 1995. Biologically active ingredients, azadirachtin and other triterpenoids. [In]: The Neem Tree, Azadirachta indica A. juss., and other Meliaceous Plants: Sources of Unique Natural Products for Integrated Pest Management, Medicine, Industry and other purposes. (Schmutterer H., Weinheim V.C.H., ed.), Germany: 35-74.

Mackanzie, H.A., Wallace H.S., 1954. The Kjeldahl determination of nitrogen. A critical study of digestion conditions, temperature, catalyst and oxidizing agents. Aust. J.Chem,7: 55-70.

McClure M.A., Kruk T.H., Misaghi.I., 1973. A method for obtaining quantities of clean Meloidogyne eggs. J. Nematol. 5: 230.

Mehdi F.S., D aw a r S ., 2008. Use of mangrove of Indus Delta in the control of root rot disease and growth promotion of crop plant. Technical Report of HEC. Department of Botany, University of Karachi.: 173.

Moju m der V., 1995. Effects on nematodes. [In]: The Neem Tree. (Schmutterer H., Weinheim V.C.H., ed.), Germany:129-150.
Sankaram A.V.B., Murthy M.M., Bhaskaraiah K., Subramanyam M., Sultana N., Sharma H.C., Leuschner K., 1986. Chemistry. Biological activity and utilization of some promising neem extracts. Third Int. Neem. Conf. Nairobi, Kenya.: 22.

S a s s e r J.N., 1980. Root knot nematode. A global menace to crop production. Plant disease. 104: 36-41.

Sasser J. N., Freckman D.W., 1987. A world perspective on nematology. The role of society. [In]: Vistas in Nematology. (Veech J.A., Dickerson D.W., ed), Hyattsville. Soc. Nematol,: 7-14.

Shanab A.B., Adwan G., Safiya A.D., Jarrar N., Adwan K., 2004. Antibacterial Activities of Some Plant Extracts Utilized in Popular Medicine in Palestine. Turkish J. Biol., 28: 99-102.

Sokal R., Rohlf F.J., 1995. Biometry: The Principals and Practices of Statistical in Biological Research. Freeman, New York.: 887.

Taylor D.P., Netscher C., 1974. An improved technique for preparing perennial pattern of Meloidogyne spp. Nematol, 20: 268.

Williams J.E., Brooker M.I.H., 1997. Eucalyptus: An introduction, in Eucalypt Ecology: Individuals to Ecosystems, (Williams J. E., Woinarski J. C. G. ed.), Cambridge University Press, Cambridge, UK: 1-15.

\section{Stosowanie nasion z lokalnych drzew do zwalczania guzaka korzeniowego Meloidogyne javanica (Treub) Chitwood oraz wspomagania wzrostu ciecierzycy pospolitej (Cicer arietinum L.) i fasoli mung (Vigna radiata $\mathbf{L}$.)}

\section{Streszczenie}

Stosowano wyciąg $\mathrm{z}$ nasion lokalnych drzew, takich jak Azadirachta indica A. Juss, Adenanthera pavonina L., Leucaena leucocephala (Lam.) de Wit i Eucalyptus spp., w postaci roztworu wodnego o stężeniu 25, 50 i $100 \%$ do zwalczania działania guzaka Meloidogyne javanica (Treub) Chitwood. Wszystkie ekstrakty z nasion wykazywały zabójcze działanie w stosunku do jaj $M$. javanica, jak również obserwowano stopniowe zmniejszanie się liczby osobników wylęgających się z jaj oraz wzrost wskaźnika śmiertelności młodocianych osobników drugiego pokolenia wraz ze wzrostem stężenia ekstraktu. Stwierdzono, że ekstrakt z nasion L. leucocephala był najskuteczniejszy w zmniejszaniu liczby osobników wylęgających się z jaj, podczas gdy $100 \%$ wskaźnik śmiertelności osobników młodocianych obserwowano w przypadku A. indica. Liczba narośli na korzeniach znacznie zmniejszyła się przy stosowaniu $100 \%$ stężenia ekstraktu z nasion A. pavonina i Eucalyptus spp., którym oddziaływano na nasiona i polewano ziemię. 
